\title{
Redes e controvérsias referentes à união homoafetiva: a produção do artefato família
}

\author{
Networks and controversies relating to homoafetiva union: the \\ production of family artifact
}

\author{
Júlio Cesar de Almeida Nobre ${ }^{1}$ \\ Ivanete da Rosa Silva de Oliveira ${ }^{2}$ \\ Felipe Boechat Barbosa ${ }^{3}$ \\ Thales Groetaers Castro e Silva ${ }^{4}$ \\ Vanilda de Araújo Cunha Monteiro de Paiva ${ }^{5}$
}

\footnotetext{
1 Graduado em Psicologia, com mestrado e doutorado em Psicossociologia de Comunidades e Ecologia Social, desenvolve pesquisas na área da produção de subjetividade e saberes a partir do referencial da Teoria Ator-rede. Docente do Centro Universitário de Volta Redonda - UniFOA.

2 Doutora em Educação na área de concentração de Políticas Públicas. Docente do Centro Universitário de Volta Redonda - UniFOA.

3 Discente do curso de Enfermagem do Centro Universitário de Volta Redonda - UniFOA.

4 Discente do curso de Direito do Centro Universitário de Volta Redonda - UniFOA.

5 Discente do curso de Serviço Social do Centro Universitário de Volta Redonda - UniFOA.
}

\section{Resumo}

O Supremo Tribunal Federal - STF, em 2011, pôs em julgamento a ADI 2477 e a ADPF 132. Em decisão favorável polêmica, acabou por reconhecer casais homossexuais como entidades familiares e detentores de direitos legais. Tal questão tem enfrentado forte resistência - inclusive religiosa. Em muitos países, essa temática também vem ganhando espaço na mídia que acaba por amplificar controvérsias inerentes aos contornos atuais daquilo que se entende por família. Tal controvérsia acaba por entrelaçar em um mesmo destino, mediadores de diversas ordens: mídia, juristas, cidadãos comuns, religiosos etc. $\mathrm{O}$ objetivo do presente artigo, portanto, é fazer uma análise do processo produtivo do artefato família na atualidade por meio de um rastreamento de mediadores diversos, controvertidas redes que o colocam em circulação. Com o foco na questão da união homoafetiva e em sintonia com a Teoria Ator-rede - TAR, nossa proposta é seguir de elo em elo a família como um efeito de redes de elementos heterogêneos e gerar um relato cartográfico.

\section{Palavras-chave}

Teoria ator-rede; família; união homoafetiva.

\begin{abstract}
The Federal Supreme Court - STF, in 2011, put on trial ADI 2477 and the ADPF 132. favorable decision controversy, has come to recognize gay couples as family entities and legal rights holders. This question has faced strong resistance - including religious. In many countries, this theme is also gaining ground in the media which ultimately amplify controversies inherent in the current contours of what is meant by family. This controversy eventually intertwine in the same destination, mediators from various sources: media, lawyers, ordinary citizens, religious etc. The purpose of this article, therefore, is an analysis of family artifact of the production process at the present through a tracking various mediators, issue networks that circulate. With the focus on the issue of homoafetiva union and in line with the Actor-Network Theory - TAR, our proposal is to follow the link to link the family as an effect of heterogeneous elements networks and generate a mapping report.
\end{abstract}

\section{Keywords}

Actor-network theory; family; homoaffective union.

\section{Como você deve citar?}

NOBRE, Julio Cesar de Almeida et al. Redes e controvérsias referentes à união homoafetiva: a produção do artefato família. Cadernos UniFOA, Volta Redonda, n. 26, p. 97-113, dez. 2014. 


\section{INTRODUÇÃO}

O artefato ${ }^{6}$ família, ao longo dos anos, vem passando por várias transformações, não somente no Brasil como também em vários outros países. Tal artefato, que circulava sem maiores controvérsias, parece se instabilizar na atualidade. Múltiplos modos de produção da família acabam por trazer fortes controvérsias para o formato nuclear tradicional. Em meio às famílias monoparentais, adotivas temporárias, de casais sem filhos, a família homoafetiva é o foco deste trabalho.

Em termos ocidentais, de um modo geral, do século $\mathrm{V}$ ao $\mathrm{XV}$, a família parecia ser uma realidade vivida, porém, sem o sentimento familiar. No final do século $\mathrm{XV}$, tal sentimento parece despontar. Em meados do século XVIII, a família passa a servir basicamente à procriação e à transmissão da linhagem. Nesse mesmo século, no Brasil, tínhamos uma família patriarcal (FREIRE, 1981), na qual o senhor exercia o poder sobre todos que habitavam a casa grande e sua propriedade agrária. Residia sob o mesmo teto a esposa, os filhos, parentes, empregados e escravos.

A partir do século XIX esse modelo familiar começa a se instabilizar e as fronteiras de uma família nuclear começam a ser delimitadas, sendo retirados dessa constituição os parentes, escravos, dentre outros. Nesse momento, passam a fazer parte do convívio da família somente o pai, a mãe e os filhos, sendo esse pai o provedor e a mãe a mantenedora do lar, submissa ao seu esposo. Salienta-se que tal modelo não se configurava como articulado apenas à realidade do Brasil, mas também circulava por muitos outros países.

$\mathrm{Na}$ atualidade, essa - até então - estável família nuclear parece encontrar resistência em sua circulação. Em meio a intensas controvérsias, a família homoafetiva, foco de análise do presente artigo, ganha significativa visibilidade quando tal temática chega ao Supremo Tribunal Federal. Nos dias 04 e 05 de maio de 2011, em sessão plenária, o STF pôs em julgamento a Ação Direta de Inconstitucionalidade / ADI 2477 e a Arguição de Descumprimento de Preceito Fundamental / ADPF132 - ambas objetivando a união estável para pessoas do mesmo sexo (DANTAS; ARAÚJO, 2012). Os respectivos ministros, tomando decisão favorável e polêmica, acabaram por reconhecer casais homossexuais como entidades familiares e, portanto, detentores de significativos direitos legais.

Salienta-se, entretanto, que as controvérsias inerentes a tal questão não se encerram com essa decisão do STF. Diversos são os atores que despontam em argumentações pró e contra tal possibilidade. Desse modo, de nó em nó, temos uma realidade sendo tecida por múltiplos e controvertidos mediadores: a mídia, políticos, instituições, ONGs, juristas, religiosos, cidadãos comuns, legislação etc.

Para a análise de coletivos complexos, entendemos que um referencial teórico-metodológico bastante fértil é a teoria Ator-Rede. A partir dessa perspectiva, tomamos a família como um efeito de redes de elementos heterogêneos, mediadores que, ao possuírem a capacidade do desvio, formam fluxos temporais produtivos rastreáveis. As controvérsias são decisivas nesse rastreamento, visto que, nesses momentos de forte instabilidade, a ação dos mediadores fica visível e passível de acompanhamento.

Assim, o foco do presente trabalho reside na análise da produção do artefato família a partir das controvérsias acerca da união homoafetiva em uma perspectiva de redes. Uma família que vem se produzindo em meio a mediadores envolvidos em diversas questões, múltiplos porta-vozes em diferentes argumentações sobre a união homoafetiva. Pretende-se, portanto, desenvolver uma cartografia descritiva da produção dessa mesma família na atualidade, buscando evidenciar sua rede heterogênea de mediações, os principais porta-vozes e as dinâmicas das conexões que articulam seus processos.

6 Em sintonia com o pensamento de Bruno Latour, utilizamos o conceito de artefato buscando enfatizar, simultaneamente, o caráter de construção - "arte" - e de solidez - "fato" - da realidade. 
A proposta do nosso trabalho é seguir os mediadores e "chamá-los a falar" por meio de um relato que não tenha a pretensão de estabilizar um novo formato rígido acerca da família na atualidade, mas que seja potente porque é rico em polifonia. Para que possamos trilhar nessa direção, realizaremos, primeiramente, um breve delineamento conceitual acerca das fronteiras da família e sua presente instabilidade diante de questões acerca da união homoafetiva.

\section{INSTABILIZAÇÕES NA FAMÍLIA: A QUESTÃO DA UNIÃO HOMOAFETIVA}

Ao abordarmos as fronteiras daquilo que entendemos por família na atualidade, podemos afirmar, em sintonia com Roudinesco (apud ZANARDO; VALENTE, 2009), que estas se configuram como uma produção de cunho temporal. Levando em consideração a potência do tempo, a atualidade parece ter produzido o conceito de casal e filhos como uma realidade fortemente articulada aos limites da família. Essa imbricação fica bastante evidente quando abordarmos uma referência tradicional como o "Novo Dicionário da Língua Portuguesa". Nessa publicação, Aurélio Buarque de Hollanda, define família como "(...) pessoas aparentadas, que vivem, em geral, na mesma casa, particularmente o pai, a mãe e os filhos" (Apud SARDENBERG, 1997, p. 3). Mais ainda, "(...) comunidade constituída por um homem e uma muIher, unidos por laço matrimonial e pelos filhos nascidos dessa união" (apud SARDENBERG, 1997, p. 3).

Zanardo e Valente (2009) parecem levar tais definições adiante quando demonstram a existência de um enlace casal e família - no ocidente - atrelado com a concepção de amor romântico. Assim, uma família entendida como nuclear, amorosa e monogâmica, delimitada pela presença de pai, mãe e filhos se impõe entre o final do século XVIII e meados do século XX. Porém, à revelia da atual potência da família nuclear, é possível identificar que diferentes modelos foram existindo no ocidente e sendo substituídos ao longo do tempo.

Philippe Ariès (apud ZANARDO; VALENTE, 1997) argumenta, por exemplo, que na época medieval - do século $V$ ao XV - já se configuravam os contornos da família como realidade vivida, embora ainda não existindo um sentimento familiar como valor. Este foi sendo desenvolvido somente a partir do século XV. Mesmo assim, tal sentimento de família segue, até o final do século XVIII, servindo, basicamente, à procriação, à transmissão da linhagem, nome e patrimônio. $O$ casamento não era fruto do amor romântico, mas sim fundado em arranjos, objetivando o lado econômico, no qual a mulher tinha um papel de objeto de troca e de agregadora de valor, pois levava para o casamento o seu dote.

A família brasileira, por sua vez, mesmo passando por várias transformações ao longo dos anos, parece igualmente se articular com tal quadro acima citado. Gilberto Freire (1981), ao produzir uma história da família no Brasil, traduz tal família, como tendo sido eminentemente patriarcal no mesmo século XVIII. Articulado também às culturas indígena, europeia e africana, nesse modelo, o grande senhor exercia seu poder sobre todos aqueles que se abrigavam em sua propriedade agrária. Os escravos, esposa, filhos, descendentes, familiares, dentre outros. A mulher, produzida como figura submissa, deveria obedecer ao marido, do mesmo modo que os filhos. Estes não poderiam se manifestar, sendo também submissos ao grande senhor e devendo, a ele, obediência e respeito. Desse modo, a casa-grande teria sido o símbolo desse tipo de organização, núcleo para onde convergia toda a vida econômica, social e política da região onde esta se situava. Sua influência se articulava com a atuação da Igreja, do Estado e demais instituições sociais e econômicas.

A partir do século XIX, Alves (2009) aponta que a família patriarcal torna-se mais instável no Brasil, dando lugar à circulação contundente de uma família nuclear: pai, mãe e filhos - o homem como provedor e a mulher como mantenedora do lar e responsável pela criação dos filhos. A forte instabilidade que ocorria, nesse momento, se articulava com a retirada de diversos elementos da fronteira da família. Agora, somente se abrigam na propriedade a mãe, o pai e os filhos. Temos aqui uma família que colocava em um mesmo circuito a casa, o casal e os laços de sangue. 
A família tradicional brasileira, desse modo, nesse momento, se produz como composta por um homem e uma mulher, ambos oriundos de famílias diferentes. A decisão relativa ao casamento era tomada pela família dos noivos. Estes deveriam cumprir um ritual com as etapas do namoro, noivado e casamento. A mulher precisaria ser entregue a seu esposo ainda virgem, isto é, sem nunca ter se envolvido fisicamente com outro homem. Ao homem, por sua vez, estaria liberada as experiências sexuais com outras mulheres, experiências estas delimitadas como uma forma de status e masculinidade (MEDINA, 1997).

Salienta-se que, desde o nascimento, a criação já seria diferenciada de acordo com o sexo do bebê. Meninas deveriam usar rosa e serem tratadas com delicadeza, ao passo que, os meninos, usariam azul e seriam educados com mais aspereza. Aos meninos, a apropriação da vida pública, como brincar nas ruas com outros meninos. As meninas deveriam ficar restritas ao mundo privado, brincando com bonecas. Desse modo, o homem se produzia como não devendo mostrar suas fraquezas, em contraponto à mulher, que seria o sexo frágil.

Formatos bem delimitados. A mulher, criada para ser boa esposa, mãe e administradora do lar, tendo responsabilidades na criação dos filhos, ao se casar, ficaria protegida por toda sua vida no mundo doméstico, restrita à vida privada e prestando obediência a seu marido, que a provê em substituição a seu pai. $O$ homem, por sua vez, detentor da liberdade na vida pública, visto que de lá retiraria o sustento da casa e da família, passaria muito tempo fora de casa trabalhando, sendo comumente visto como uma figura autoritária pelos filhos. Nesse modelo de família nuclear, composta por pai, mãe e filhos, a preocupação é a de procriar e criar a prole.

Nos últimos anos, no Brasil, as estatísticas vêm argumentando ainda no sentido da predominância dessa família nuclear. Segundo Goldani (apud ZANARDO; VALENTE, 1997), no final da década de 80, a maioria de brasileiros e demais residentes no país viviam em unidades domésticas formadas por esse tipo de vínculo. Do total de domicílios particulares pesquisados pelo IBGE em 1989, 92,6\% organizavam-se ao redor de uma família ${ }^{7}$, sendo que, desse total, $61 \%$ eram de casais com filhos, $12,55 \%$ de casais sem filhos, $15,2 \%$ de famílias monoparentais e $3,4 \%$ tinham outros arranjos familiares (SARDENBERG, 1997). Tais estatísticas acabam por traduzir que, em um passado recente, o modelo de família nuclear ainda imperava.

Porém, parece que aquilo que viemos entendendo por família até então se encontra com muita dificuldade em se manter estável. Um fator que parece contribuir para tal instabilidade tem sido a presença de diversas configurações possíveis para os contornos familiares. Se por um lado, temos atores a traduzir família como dotada de vínculos mais fluidos, relações estabelecidas de modo fugaz, por outro, como já abordamos anteriormente, temos argumentos que ainda revelam uma forte presença de arranjos familiares mais tradicionais, apoiados no conceito de pai, mãe e filho. Nesses termos, aquilo que entendemos por família parece bastante problemático no momento.

A família contemporânea parece nos remeter a formatos diferentes, na qual o modelo tradicional - pai, mãe e filhos - não deixa de existir, mas se instabiliza com a presença e circulação de outros modos de família. As famílias extensas, que incluem três ou quatro gerações; as famílias substitutas, formadas por meio da guarda, tutela e adoção; as famílias monoparenterais, que se instauram apenas quando um dos pais arca com as responsabilidades de criar o filho ou filhos; as famílias adotivas temporárias; as famílias inter-raciais; as famílias de casais sem filhos; as famílias unipessoais, nas quais a pessoa opta por viver sozinha, dentre outras.

\footnotetext{
7 A definição de família adotada, nesse momento, pelo IBGE é de uma unidade doméstica residencial - um lar - não se articulando com um grupo de pessoas conviventes que mantêm vínculos de parentesco resultantes de consanguinidade ou de adoção.
} 
A família, da forma como vem se produzindo nos últimos tempos, parece impossibilitar sua identificação a partir de um modelo único ou ideal. Na tradução de Oliveira (2009), diferentemente da abordagem tradicional, ela antes sugere uma manifestação de múltiplas trajetórias, arranjos diversificados em espaços e organizações singulares. Um conceito de família, como nos apresenta Gomes (apud BOTTOLI et all, 2012), baseada na união exclusiva de um homem e uma mulher, que se inicia por amor, com a esperança de que o destino lhes seja favorável e que seja definitiva, parece não mais se sustentar como única possibilidade. Em meio à intensa turbulência por que vem passando a família na atualidade, muito se tem discutido acerca da união homoafetiva e sua relação com o modelo mais tradicional de família conhecido. Tais controvérsias acabam por envolver atores de diversas ordens, como aqueles do âmbito jurídico, espaço este onde a temática da união homoafetiva ganhou forte potência quando o Supremo Tribunal Federal - STF - se reuniu para julgar a ADI 4277 e a ADPF 132 - que tratavam do reconhecimento da união entre pessoas do mesmo sexo como entidade familiar (DANTAS; ARAÚJO, 2012).

Em 25 de fevereiro de 2008, fora apresentada ao STF a Arguição de Descumprimento de Preceito Fundamental - ADPF 132, de autoria do Governador do Rio de Janeiro, Sergio Cabral. A ADPF teve por enfoque a promoção do direito à isonomia, bem como a liberdade e a dignidade da pessoa humana. A principal solicitação trazida pela respectiva ação foi o requerimento da efetivação do art. 1723 do Código Civil brasileiro para a união homoafetiva. Este sinaliza em seu caput que: "É reconhecida como entidade familiar a união estável entre o homem e a mulher, configurada na convivência pública, contínua e duradoura e estabelecida com o objetivo de constituição de família (BRASIL, 2002)".

Objetivava-se que o STF viesse a traduzir o Estatuto dos Servidores Civis do Estado do Rio de Janeiro em sintonia com a Constituição do país, formalizando que, decisões judiciais, estabelecendo desigualdade jurídica entre uniões homoafetivas e uniões estáveis estariam em contradição com direitos fundamentais. Mais ainda, solicitava-se que, caso houvesse a derrota da ADPF, esta fosse recebida como uma ADI - Ação de Inconstitucionalidade.

Já em 02 de julho de 2009, a Procuradoria Geral da República propôs a ADPF 178, que terminou sendo recebida pelo então presidente do STF, Ministro Gilmar Mendes, como a ADI 4277. O objetivo principal era que a Suprema Corte declarasse como obrigatório o reconhecimento da união homoafetiva como entidade familiar. Tal reconhecimento se daria desde que preenchidos os mesmos requisitos necessários para a configuração da união estável entre homem e mulher. A proposta era de que os mesmos deveres e direitos originários da união estável fossem estendidos aos companheiros nas uniões homoafetivas.

A partir desses movimentos, houve um posterior julgamento, ocorrido em 04 de maio de 2011, quando o relator das ações, o ministro Ayres Britto, votou convictamente no sentido de empregar nova interpretação, conforme a Constituição Federal, para excluir qualquer significado do artigo 1.723 do Código Civil - Lei n 10.406 de 10 de janeiro de 2002 - que viesse a impedir o reconhecimento da união entre pessoas do mesmo sexo como entidade familiar. Tal artigo traz a previsão de que:

Art. 1.723. É reconhecida como entidade familiar a união estável entre o homem e a mulher, configurada na convivência pública, contínua e duradoura e estabelecida com o objetivo de constituição de família.

$\S 1^{\circ} \mathrm{A}$ união estável não se constituirá se ocorrerem os impedimentos do art. 1.521; não se aplicando a incidência do inciso VI no caso de a pessoa casada se achar separada de fato ou judicialmente.

$\S 2^{\circ}$ As causas suspensivas do art. 1.523 não impedirão a caracterização da união estável (BRASIL, 2002).

0 ministro argumentara que o artigo $3^{\circ}$, inciso IV da Constituição Federal, veda qualquer discriminação em virtude de sexo, raça, cor e que ninguém poderá ser diminuído ou discriminado em função de sua preferência sexual. Nesse sentido, o ministro articula os opositores da união homoafetiva como dotados de atitude discriminatória colidindo, portanto, com o artigo supracitado. 
Na prática do julgamento, uma intensa controvérsia acaba por se articular com o processo que ocorre no STF. Desse modo, a Suprema Corte, ao imbricar-se com a produção de uma normatividade reconhecedora de qualquer tipo de união estável, acaba por atuar fortemente em meio a turbulências relativas aos contornos daquilo que concebemos por família na atualidade.

Em tal controvertido processo de produção de normatividade, muitos são os mediadores atuando, a fazer circular aquilo que entendemos por família na mesma proporção em que argumentam. Por um lado, vemos - já há algum tempo - inúmeras traduções que parecem produzir um conceito ampliado de família:

\begin{abstract}
Creio que há algo de novo no Direito da Família: a vontade de vencer os limites ridículos da acomodação intelectual. Porém, tudo será em vão sem a assunção pela sociedade - enquanto Estado, comunidade acadêmica, organizações não governamentais - de uma postura responsável em relação à família - lato sensu. Transformando o texto da Constituição Federal em letra viva (COLARES, 2001). Por outro, temos argumentos que acabam por traduzir as uniões entre pessoas do mesmo sexo como deslocadas do conceito de casamento, visto que este, em muito, veio sendo propagado como objetivando a reprodução da espécie: crescei e multiplicai-vos ${ }^{8}$.
\end{abstract}

Diversas são as questões comumente levantadas acerca da união homoafetiva. Com o intuito de analisar as controvérsias produtoras daquilo que se concebe por família em meio às questões acerca da união homoafetiva, o presente trabalho não tem por finalidade dar uma resposta em definitivo sobre tal artefato, apresentando um conceito que se queira mais profundo e sólido que outro. Não almejamos nada além do terreno plano das mediações a constituir a família na justa medida de suas ações. Nesse sentido, entendemos o referencial da Teoria Ator-rede como bastante fértil na abordagem de controvertidos coletivos.

\title{
3 O REFERENCIAL TEÓRICO DA TEORIA ATOR-REDE - TAR
}

A partir do abordado anteriormente, pode-se afirmar que, na atualidade, a família parece ser alvo de fortes controvérsias. Novos atores despontam, trazendo significativa turbulência para os alicerces dessa instituição que, até então, circulava sem maiores instabilidades, sem grandes questionamentos. Em tal terreno sinuoso sobre do conceito de família, alvo de controvérsias mobilizadas pelos questionamentos acerca da união homoafetiva, entendemos que uma perspectiva apoiada no conceito de redes sociotécnicas pode auxiliar bastante no rastreamento de circuitos de mediadores que delineiam formatos na justa medida de suas ações, seus desvios.

A TAR, desenvolvida por Bruno Latour, dentre outros, nos remete a articulações, desvios produtores de existência levados a cabo por mediadores que não se resumem a condição humana. Temos aqui um entrelaçamento de humanos e não humanos. Nesse sentido, actantes são entidades atuantes, que formam redes, que promovem mudanças no coletivo de mediadores que compõem a realidade. Salienta-se que os não humanos possuem papel importante no referencial TAR, visto que estes, assim como os humanos, irão povoar a produção dos fatos.

Ao abordarmos o referencial das redes, devemos ter por foco o conceito de mediador. Estes seriam os responsáveis pelas constantes redefinições, desvios que modificam a realidade. Novas questões vão surgindo e pressionando as velhas, em que um novo coletivo começa a ser criado, tecendo uma nova realidade. Toda realidade, portanto, se mantém sustentada por um circuito de mediações caracterizado como um fluxo de deslocamentos. De nó em nó, mediador em mediador, um coletivo se fabrica. Para

\footnotetext{
8 Diante da infertilidade dos casais homoafetivos, muitas vertentes religiosas passaram a repudiá-los. O Pastor Silas Malafaia, pastor pentecostal, vinculado à Assembleia de Deus, líder evangélico da Igreja Assembleia de Deus Vitória em Cristo, por exemplo, é um dos importantes mediadores que, em inúmeras entrevistas e reuniões, demonstra argumento contrário a união homoafetiva. Seu foco de crítica parece estar fortemente articulado ao entendimento do que vem a ser uma família, com argumentações que apontam tal união como uma quebra de preceitos existentes na Bíblia.
} 
um melhor entendimento, criemos a seguinte imagem: uma peça de teatro com os atores em cena e uma ávida plateia assistindo ao respectivo show. Com suas atenções voltadas para o espetáculo, não se dão conta de que o maior show não está ao alcance de seus olhos. Os bastidores onde, para que a mágica da cena aconteça, cada elemento precisa manter uma sincronia coletiva. $\mathrm{Na}$ "cozinha dos fatos" existe todo um trabalho coletivo, muitas vezes, invisível.

Quando um desempenho acontece de modo sincronizado, sem maiores controvérsias, estamos diante da formação de uma caixa-preta. Esta, portanto, acontece apenas quando inexistem questionamentos, instabilidades, isto é, quando humanos e não humanos estão em uma mesma sintonia coletiva. Porém, tal vivência de solidez não tem garantias de manutenção. Se algo na rede de trabalho sai do eixo, o inesperado traz questionamentos acerca da realidade e robustez dos fatos. Entramos em um campo de controvérsias e a caixa-preta se abre. Estamos diante daquilo que Latour denomina caixa-cinza. Tais processos indicam que um artefato não conseguiu se estabilizar, tendo esse social, portanto, retornado ao campo das discussões e turbulências. Diante das aberturas e fechamentos de caixas-pretas, temos um social concebido como fluxos, caracterizado por um dinamismo temporal, onde os espaços dependem dos circuitos para se sustentar.

Em um social tão fugaz e sem garantias, a TAR sinaliza algumas coordenadas necessárias para aqueles que se interessam pela abordagem de redes (LATOUR, 2000). A) Devemos objetivar um fato sempre em ação, situando-nos em momentos de construção de caixas-pretas; B) a condição de artificialidade ou de natureza de um fato é sempre efeito dos processos de mediação dos coletivos; C) a estabilização de um fato é uma consequência da resolução das controvérsias envolvidas e nunca sua causa; D) a estabilidade da sociedade é igualmente uma consequência da resolução de controvérsias; E) o pesquisador deve se colocar em uma posição simétrica diante do estabelecimento de qualquer polaridade, rastreando os nós que estão sendo amarrados nesses processos; F) faz-se importante focalizar a extensão da rede, que é construída diante de argumentos acusatórios de irracionalidade, bem como na busca de explicações sociais ou lógicas que justifiquem tal acusação e $G$ ) deve-se rastrear a rede que sustenta qualquer qualidade especial, a qual atribuímos a condição de solidez factual.

Seguindo tais passos propostos por Latour, teremos pistas a serem seguidas, mediadores em ação a construírem caminhos, possibilidades, realidades. Desse modo, a proposta é, ao seguirmos tais pistas, desenvolvermos um relato derivado do próprio rastreamento (LATOUR, 2008). Um relato potente porque rico em mediadores. Dar voz aos diferentes actantes envolvidos na questão da união homoafetiva, um controvertido coletivo cuja realidade daquilo que entendemos por família parece adquirir significativa instabilidade, revelando sua condição de caixa-cinza.

Tal referencial, portanto, possibilita uma análise da "cozinha do fato" família em termos de uma abertura da caixa-preta, imbricada com um controvertido coletivo, a envolver a temática da união homoafetiva. Uma cartografia de circuitos de mediações humanas e não humanas levadas à frente, na justa proporção das ações de disjunção e conjunção levadas adiante. Uma tessitura que envolve elementos diversos: leis, mídia, academia, cidadão comuns, religião dentre outros.

Desse modo, entendemos que a controvérsia jurídica acerca da união homoafetiva instaura-se em um momento de significativa abertura da caixa-preta família. Assim, entendemos que os argumentos jurídicos presentes em artigos diversos, em muito, nos servem como importantes portas de entrada para o estudo acerca da produção de contornos atuais desse artefato. Faz-se mister salientar que a grande mídia também se revela como singular porta de entrada na respectiva controvérsia, visto que esta não apenas pauta o tema, mas o traduz e reverbera intensamente. 


\title{
4 ANALISANDO CONTROVÉRSIAS ACERCA DA UNIÃO HOMOAFETIVA: O ARTEFATO FAMÍLIA EM AÇÃO
}

Conforme já abordamos anteriormente, em julgamento, ocorrido no ano de 2011, o ministro Ayres Britto votou de modo convicto por uma nova interpretação conforme a Constituição Federal, objetivando excluir um significado do artigo 1.723, do Código Civil - Lei $n^{\circ} 10.406$ de 10 de janeiro de 2002 - que impedisse a potencialização da união entre pessoas do mesmo sexo e seu reconhecimento como uma entidade familiar. Nesse sentido, os ministros Luiz Fux, Ricardo Lewandowski, Joaquim Barbosa, Gilmar Mendes, Marco Aurélio, Celso de Mello e Cezar Peluso, bem como as ministras Cármen Lúcia e Ellen Gracie, acompanharam o entendimento do ministro Ayres Britto pela procedência das ações. Todos os dez ministros votantes no julgamento da ADPF 132 e ADI 4277 manifestaram-se pelo entendimento da união homoafetiva como entidade familiar.

Vale ressaltar que a Suprema Corte brasileira teve um posicionamento extremamente homogêneo diante da temática acerca da união homoafetiva. Desse modo, potente foi sua atuação no sentido do delineamento dos contornos acerca do que vem a ser considerado como família, articulando a defesa desses limites impostos com a necessidade de se reprimir de forma árdua e incessante qualquer tipo de intolerância ou discriminação. Tal processo parece estar acontecendo em maior escala, não trazendo instabilidades para as fronteiras familiares apenas no Brasil.

Em matéria da Revista Veja, podemos observar na realidade britânica que:

\begin{abstract}
Casais homossexuais da Inglaterra e do País de Gales, no Reino Unido, aproveitaram para oficializar sua união logo nos primeiros minutos deste sábado, dia em que entrou em vigor a nova lei sobre o casamento gay. As regras não valem para toda a Grã-Bretanha, já que Escócia aprovou sua própria lei, que entrará em vigor no fim do ano, e a Assembleia norte-irlandesa ainda não legislou a respeito. Pesquisas de opinião mostram que quase dois terços dos britânicos apoiam a união homossexual (...). No país não foram registrados grandes protestos contra a lei, ao contrário do que aconteceu na vizinha França (VEJA 2014).
\end{abstract}

No site jurídico Jus Navigandi, há apontamentos que demonstram a participação da América Latina, nessa mesma época, das controvérsias relativas à temática da legalização da união civil entre pessoas do mesmo sexo.

A capital da Argentina tornou-se, em 13 de dezembro de 2002, a primeira cidade da América Latina a legalizar a união civil de homossexuais, depois de um debate acalorado na câmara local, interrompido em várias ocasiões. Os legisladores de Buenos Aires aprovaram um projeto que representa amparo legal para casais do mesmo sexo, dando-Ihes certos direitos conjugais, ainda que sem permitir o casamento ou a adoção (BORELLI, 2003).

No Brasil, o casamento vinha, nesse mesmo momento, sendo traduzido como algo a ser aceito somente quando envolvesse homem e mulher. 0 Código Civil, mesmo não definindo o conceito de casamento, deixa entendido que este é um ato efetivado por um homem e uma mulher, fazendo referências que articulam a concepção de cônjuges com marido e mulher. Do mesmo modo, a Constituição Federal também não sinaliza o que vem a ser casamento, mas no Art. $226, \S 5^{\circ}$, desenvolve as mesmas fronteiras desse conceito, quando argumenta sobre o exercício dos direitos e deveres na sociedade conjugal. 0 respectivo artigo aponta que estes são praticados tanto pelo homem quanto pela mulher. Mais uma vez casal articulado à diferença dos sexos, sendo esta um requisito fundamental para sua própria condição de realidade.

Ainda em 2002, no mês de janeiro, uma situação explode na mídia brasileira, amplificando bastante as controvérsias em relação à formalização legal dos casais homoafetivos na época. Após o falecimento da cantora Cássia Eller, mãe de um menino de 8 anos chamado informalmente de Chico, a Justiça do Rio de Janeiro concede sua guarda provisória à companheira, com quem a artista manteve uma relação homoafetiva por quatorze anos. A potência desse caso traz tal polêmica para o cotidiano das relações de um modo bastante intenso, fazendo reverberar diferentes opiniões naquele momento. 
Antes de tal debate midiático a envolver Chico, cabe citar a atuação da senadora Marta Suplicy e seu projeto de Lei n ${ }^{\circ} 1151 / 95$ (na época, Deputada Federal). Tal projeto objetivava disciplinar a união civil entre pessoas do mesmo sexo. Na sua justificativa, a parlamentar asseverava que: "Este Projeto pretende fazer valer o direito à orientação sexual, hetero, bi, ou homossexual, enquanto expressão de direitos inerentes à pessoa humana. (...) Essas pessoas só buscam o respeito às suas uniões (...) devidos pela sociedade e pelo Estado" (SUPLICY, 1995: 4-5).

O projeto buscava regulamentar, reconhecer e conferir direitos e obrigações decorrentes da união homóloga, não tendo como objetivo incentivar ou fazer qualquer apologia à homossexualidade. De qualquer modo, temos aqui um argumento que coloca a união civil articulada com orientações sexuais diversas e à dignidade humana. Mais ainda, Marta Suplicy tem sido um importante porta-voz nesse sentido na atualidade, por continuar a defender os direitos da união homossexual, como citado na reportagem de Eunice Pinheiro, de agosto de 2011, do site "PT no Senado".

A senadora Marta Suplicy (PT-SP) elogiou a sugestão de Proposta de Emenda Constitucional (PEC) que pretende assegurar direitos aos gays, lésbicas, transexuais e travestis de todo o País, como o de casamento civil, adoção e licença natalidade de 180 dias (PINHEIRO, 2011).

O texto da respectiva PEC, elaborado pela Comissão Especial de Diversidade Sexual da Ordem dos Advogados do Brasil (OAB), foi entregue à senadora juntamente com um projeto de criação do denominado Estatuto da Diversidade Sexual. O projeto objetivava adequar à legislação brasileira a todas as decisões tomadas pelo Supremo Tribunal Federal (STF) em relação à população LGBTT - Lésbicas Gays Bissexuais Transexuais e Travestis, como a união estável para casais homossexuais. Desse modo, tais casais ganhariam direitos tais como: adoção de menores, heranças de companheiros, pensões alimentícias, dentre outros.

No site de entretenimento UOL, em parceira com a revista TPM, encontramos outra figura importante na luta pelo casamento homoafetivo. A juíza Berenice, na respectiva matéria on line conclui que

é bom que fique claro: os gays estão casando no Brasil. E do mesmo jeito que a sua vó fez nos anos 50, sua mãe
nos anos 70 e sua amiga mês passado: no papel. Não dá para explicar o porquê sem trazer à tona o nome da
advogada e juíza aposentada Maria Berenice Dias, 65 anos. Foi ela quem escreveu o primeiro livro sobre direito
homo afetivo do Brasil, quem abriu o primeiro escritório do ramo e quem decidiu, ao lado de colegas do Tribunal
de Justiça do Rio Grande do Sul, que um casal de homens assim o era, pela primeira vez, em 2001. (...) "Comecei
a pesquisar e não acreditei que ninguém nunca tinha olhado e dito: 'Alô, ali tem uma família'. E não uma socie-
dade civil, como tantos advogados e juízes defendiam". A diferença na definição está no centro do termo que ela
cunhou para tratar do tema: homo afetivo. "Família é relação de afeto (GONZÁLEZ, 2013).

Temos aqui a família claramente traduzida como circulando pela produção de um conceito de "relação homoafetiva" e articulada com o afeto. Em consonância, a Juíza Berenice, o deputado federal pelo Estado do Rio de Janeiro Jean Willys, homossexual assumido e importante ativista na temática, expõe o seguinte argumento no site Casamento Igualitário, de sua autoria:

Vejam só quantas coisas já mudaram. Após as sentenças do STF - que reconheceu que os casais do mesmo sexo podem constituir uma família e têm direito à união estável com os mesmos requisitos e efeitos que as uniões estáveis de homem e mulher - e do STJ - que reconheceu o direito ao casamento civil de um casal de lésbicas do Rio Grande do Sul -, diferentes casais começaram a inscrever suas uniões estáveis e pedir à justiça a conversão em casamento. Teve uma primeira sentença favorável, e depois outra, e mais outra. Logo os juízes começaram a admitir que, se os casais do mesmo sexo podem registrar a união estável e convertê-la em casamento, não há razão para que eles não possam se casar de forma direta. E as corregedorias estaduais começaram a regulamentar essa possibilidade em até treze estados, mais o Distrito Federal. Em todos esses estados, qualquer casal poderia realizar seu casamento civil. Era só ir no cartório e marcar a data (WILLYS, s/d).

Podemos notar que, cada vez mais, é reivindicado o casamento homoafetivo para que se tenham seus direitos assegurados, direitos simbólicos inclusive, articulados à sensação de igualdade com os casamentos feitos entre homem e mulher. Willys prossegue: 
(...) a igualdade não tem CEP (...). Precisávamos de uma única regra para todo o país. Meu mandato entrou com um pedido no Conselho Nacional da Justiça (CNJ) e, pouco depois, o juiz Joaquim Barbosa, presidente do Conselho - e do STF - assinou a decisão 175/2013, que regulamenta o casamento civil entre pessoas do mesmo sexo em todo o Brasil. Desde 14 de maio de 2013, todos os brasileiros e todas as brasileiras têm direito ao casamento civil! Falta, ainda, que o Legislativo entenda o que o Judiciário já entendeu e se liberte das amarras do fundamentalismo religioso (...) e aprove os projetos de lei e emenda constitucional que o meu mandato apresentou, para garantir o direito ao casamento igualitário na Constituição e no Código Civil (WILLYS, s/d).

Temos aqui a tradução do Legislativo brasileiro como opositor do casamento homoafetivo, articulado com a homofobia, o machismo e o fundamentalismo, ao passo que o Judiciário é delimitado como aliado. $O$ deputado continua:

Isso é necessário por duas razões. Em primeiro lugar, para garantir que essa conquista seja irreversível. Em segundo lugar, porque as decisões do Congresso, diferentemente das decisões do Judiciário, são antecedidas por um debate público que envolve o conjunto das forças políticas e promove, como consequência, um debate social que - foi provado nos países que já fizeram - tem um valor pedagógico muito importante para combater os preconceitos e ajudar a construir uma sociedade mais justa (WILLYS, s/d).

Podemos perceber que o objetivo da Juíza e de Jean Willys parece ir além da simples abordagem do tema da homossexualidade e seus direitos. Tem como finalidade expor a luta incessante e intermitente desse grupo, em prol de uma isonomia no mundo matrimonial, social e constituinte de família, sem quaisquer burocracias ou preconceitos. Para tal, o deputado traz como aliado a experiência de outros países com o debate público acerca da temática.

Willys, ao compartilhar, no site YouTube, o vídeo intitulado "Álbum família pela igualdade. Natal, 2012", ainda argumenta que:

(...) lideranças religiosas, incluindo o Papa Bento XVI que considera que a homossexualidade e os casais homoafetivos e o direito ao casamento civil homoafetivo destruirão a família. Isso não é verdade. Nós não vamos destruir a família. Ao contrário, nós queremos fortalecer as famílias na sua diversidade. Famílias no plural, pois não há um só modelo de família, nem um só modelo de ser feliz (WILLYS, 2012).

Temos uma clara tradução da Igreja Católica como uma rival da causa, bem como a tentativa da produção de uma família entendida em aspectos mais amplos, sempre articulada com felicidade e afeto.

Mas se, por um lado encontramos uma formação de grupos detentores de argumentos que parecem fazer a família circular por novos arranjos, por outro lado, anti-grupos contra-argumentam. O líder da Igreja Assembléia de Deus Vitória em Cristo, o pastor Silas Malafaia, em diversas entrevistas a jornais, rádios e televisão, profere declarações, nas quais defende, veementemente, um modelo tradicionalista de família. Nessas entrevistas, o pastor expõe sua opinião sobre o casamento homossexual e o homossexualismo de forma genérica: "Eu amo os homossexuais como eu amo os bandidos" (SBT, 2013). "Eu não acredito que dois homens e duas mulheres tenham a capacidade de criar um ser humano" (SBT, 2013).

O pastor, em matéria do site GNotícias intitulada "É possível a um homossexual abandonar essa prática?", argumenta que a prática homossexual é reprovada pela Bíblia, e discorda da tese que afirma ser o homossexualismo uma constituição genética.

\footnotetext{
O ser humano é um ser social e vive sob a influência de modelos, padrões. Os psicólogos são unânimes em dizer que mais importante do que a determinação genética para uma criança decidir a sua preferência sexual é a maneira como ela é criada. Não há determinismo genético. E, se é uma questão de comportamento, um homossexual pode abandonar essa prática e tornar-se heterossexual (CHAGAS, 2013).
}

Vemos aqui que o respectivo pastor, importante porta-voz nessa temática, desvincula o conceito de família de uma questão biológica e procura trazer a psicologia para a cena. No campo teológico, o pastor diz que "(...) a menos que eles se arrependam dessa prática abominável aos olhos de Deus e 
convertam-se a Cristo, serão condenados a passar a eternidade no inferno, um lugar de pranto, dor e ranger de dentes" (CHAGAS, 2013).

Malafaia, ainda, aponta que, para deixar de ser homossexual, o indivíduo deveria reconhecer primeiramente que pecou, sendo tal reconhecimento uma questão individual.

\begin{abstract}
Embora remédios e técnicas terapêuticas não possam transformar um homossexual em heterossexual, se ele reconhecer seu erro, confessá-lo a Deus, pedir perdão e entregar sua vida a Cristo, será justificado pelo sangue de Jesus, liberto do pecado que o domina e transformado em uma nova criatura. Mas, para isso, é preciso, sobretudo, que o homossexual tenha consciência da sua condição pecaminosa e queira dar um novo rumo à sua vida (CHAGAS, 2013).
\end{abstract}

Temos o casal homossexual produzido como pecado, erro a ser confessado. No final do artigo, 0 pastor procura desarticular seu argumento da homofobia, ao afirmar que ama os homossexuais, sendo contra uma simples aversão violenta. Diz afirmar, porém, “(...) seus princípios éticos, morais e espirituais que se baseiam no conhecimento que temos da Lei e da vontade de Deus para o ser humano ter uma vida plena, feliz e eterna" (CHAGAS, 2013). Em junho de 2013, aconteceu em Brasília uma manifestação evangélica convocada por pastores diversos e liderada por Malafaia. Tal evento buscava defender a liberdade religiosa. Malafaia foi quem mais discursou, declarando que o

(...) crime de opinião foi extinto e o ativismo gay quer dizer que minha opinião sobre a união homoafetiva é crime. Nos chamam de fundamentalistas, mas eles são fundamentalistas de lixo moral, o ativismo gay é o fundamentalismo do lixo moral (...). Tentam comparar com racismo, mas raça é condição, não se pede pra ser negro, moreno ou branco. Homossexualidade é comportamento. Ninguém nasce homossexual (BRESCIANI, 2013).

Temos aqui um argumento que procura articular união homoafetiva com um ativismo gay entendido como aparentado ao extinto crime de opinião e desvincular o seu próprio argumento de um preconceito nos moldes do racismo.

Em matéria intitulada "Em atos contra gays, Malafaia diz que união homoafetiva é crime", sobre a mesma manifestação do dia 05 de junho de 2013, o jornal O Estado de São Paulo on line reverbera uma tradução de família bastante clara disseminada por tais actantes:

(...) Um dos mais ovacionados pelo público foi o pastor Marco Feliciano (PSC-SP), presidente da comissão de Direitos Humanos da Casa. Ele citou (...) os ataques que sofreu desde que assumiu a comissão. "Depois de 90 dias no vale da sombra, das mortes, estou aqui para dizer que represento vocês", disse Feliciano. Ele afirmou ainda que a "família" tem de vir antes do governo e da sociedade (BRESCIANI, 2013).

Encontra-se uma clara tradução de família homoafetiva como uma escolha passível de criminalização - quando atenta-se para o título da matéria. O pastor e deputado federal Marco Feliciano, do PSC (Partido Social Cristão), ao traduzir família como um ponto mais fundamental que o Governo e a própria sociedade, parece apontar para um suposto dever do Estado que é chamado a argumentar por tal criminalização. Em uma entrevista para a Folha Rondoniense (2013), o deputado traduz o casamento homoafetivo como um lixo moral, quando argumenta que

(...) o senhor acha que dentro de alguns anos ou décadas, ouviremos na celebração de algum casamento qualquer o padre ou pastor perguntar: "Senhor Fulano de tal, o senhor aceita o senhor Sicrano de tal como seu legitimo esposo?" e respondeu da seguinte forma: "Já existe isso em igrejas "protestantes"... Eu espero que em breve o mundo acorde desta overdose de lixo moral", mostrando uma posição firme contra o casamento de pessoas do mesmo sexo. Considerando algo imoral perante a sociedade (OLIVEIRA, 2013).

Em detrimento dos argumentos, propostas e lutas de atores, como a Juíza Berenice e o deputado Jean Willys, no site Estadão, podemos encontrar a seguinte matéria que advoga pela existência de uma "bancada evangélica": 
A Comissão de Direitos Humanos, comandada pelo pastor Marco Feliciano (PSC - SP) e dominada pela bancada evangélica, aprovou nesta quarta- feira, 20 , dois projetos para tentar retirar direitos obtidos pelos homossexuais e rejeitou um terceiro que desejava garantir em lei outro direito. Todas as propostas serão submetidas ainda a outras comissões e ao plenário da Casa. 0 primeiro projeto aprovado prevê um plebiscito para decidir sobre o reconhecimento da união civil de pessoas do mesmo sexo. A proposta, de autoria de André Zacharow (PMDB-PR) e relatada por Marcos Rogério (PDT-RO), tem como efeito prático tentar derrubar a decisão do Supremo Tribunal Federal (STF) que legalizou este tipo de união. A segunda proposta, na mesma linha, de autoria de Arolde de Oliveira (PSD- RJ) e relatada por Pastor Eurico (PSD-PE), quer sustar por decreto legislativo a resolução do Conselho Nacional de Justiça (CNJ) que obrigou cartórios de todo país a registrar casamentos de homossexuais. As duas propostas irão a outras comissões e a plenário (BRESCIANI, 2013).

Desse modo, temos claramente grupos dispostos em oposição. A exposição de tais argumentos acaba por revelar intensas reivindicações por partes de diferentes atores/mediadores que, ao se utilizarem de seus preceitos e conviç̧ões, promovem desvios e impactos sociais. Desse modo, os conflitos gerados acabam por trazer controvérsias para a família, formando grupos dispostos em oposição.

Uma matéria no jornal Carta Capital (2013) informa igualmente que, na atual luta pela aprovação do casamento homoafetivo, a Comissão de Direitos Humanos e Minorias da Câmara dos Deputados, presidida pelo próprio pastor Feliciano, aprovou em novembro de 2013 , a realização de um plebiscito para consultar a opinião da população sobre a união civil entre pessoas do mesmo sexo. E, parecendo assumir uma posição contrária a tal plebiscito, o respectivo jornal traduz o projeto como uma derrota para o movimento LGBT já que, na prática, viria a permitir que a maioria da população pudesse dar o seu aval (ou não) ao direito de uma minoria. Acrescenta-se a tal derrota a aprovação, na mesma reunião, de um segundo projeto que suspende a decisão do Conselho Nacional de Justiça (CNJ), que abriu espaço para os cartórios aceitarem a celebração de casamentos civis de casais do mesmo sexo, bem como a conversão para casamento, da união estável entre pessoas do mesmo sexo (CARTA CAPITAL, 2013).

No site Terra (2013), encontramos matéria que aborda a temática do Projeto Escola Sem Homofobia:

O kit de combate à homofobia - que integra o projeto Escola sem Homofobia - foi desenvolvido por diversas enti-
dades não governamentais, com a supervisão do Ministério da Educação, para ser distribuído a alunos do ensino
médio de 6 mil escolas públicas previamente selecionadas. No entanto, após pressão das bancadas religiosas no
Congresso Nacional, a presidente vetou o material em maio de 2011 . Segundo Dilma, o kit era inadequado e fazia
propaganda de orientações sexuais. O kit é composto de um caderno com orientações sobre atividades que podem
ser desenvolvidas pelos professores em sala de aula; de seis boletins destinados aos estudantes; de cartazes
para divulgar o programa na comunidade escolar, de cartas endereçadas a professores, além de três vídeos para
serem trabalhados em sala de aula. O convênio para a preparação do material (...) incluía também pesquisas,
seminários e atividades de capacitação para os educadores que fossem utilizá-los nas escolas (CHAGAS, 2013).

Conforme o argumento da respectiva matéria, a bancada evangélica do Congresso exerceu forte resistência ao projeto. Ao abordarmos o Site Família Bolsonaro, que representa interesses do deputado federal Jair Bolsonaro, encontramos argumentos críticos aproximados a tais posicionamentos evangélicos. Diante do livro didático "Menino Brinca de Boneca?", livro este que seria distribuído pelo governo brasileiro no kit presente no projeto Escola sem Homofobia, temos a seguinte colocação: "Caso seus filhos tenham este exemplar em suas mochilas, fiquem atentos, pois certamente estão recebendo carga de informações estimulando o homossexualismo em suas cabeças" (SITE FAMÍLIA BOLSONARO, 2012). Deparamo-nos aqui com uma tradução de tal leitura como sendo má influência, voltada para o homossexualismo nas crianças e potencialmente negativa no que tange à família. Ainda, em mesma postagem, o site ao abordar o mesmo kit, diante de um jogo da memória contendo vários modelos de família, afirma: "É nitidamente fácil constatar as mensagens subliminares envolvendo o homossexualismo e pedofilia, que são exploradas durante as tarefas ensinadas" (SITE FAMÍLIA BOLSONARO, 2012). Temos aqui a produção de um tipo de ligação entre homossexualidade e pedofilia, claramente criminalizando e negando esse tipo de família como aceitável.

Em relação à sua eleição como deputado federal, em entrevista ao jornal O Globo (GALDO, 2014), Jair Bolsonaro disse ainda não concordar com quem afirma que ele tenha sido eleito com base numa agenda chamada de "antigay". o político acaba por afirmar que, se definirmos homofobia como uma atitude respeitosa diante da família, bem como manter um desejo de que as crianças percorram seus 
destinos previamente programados ao nascerem, então ele é homofóbico. Família, mais uma vez, é traduzida como naturalmente pré-definida por uma condição rígida em relação ao sexo biológico.

Na Conferência Nacional LGBT de 2013, Maria do Rosário, na época, ministra da Secretaria de Direitos Humanos, afırmou que se existe o ensino de que o sexo homem/mulher é natural, a homossexualidade deveria também ser apresentada como natural e menos que isso seria, no entendimento dela, preconceito e violência. Temos aqui a tradução da família homoafetiva como natural e, portanto, se algo é natural, tem o direito de existir e de receber respeito. Salienta-se que, nessa mesma conferência, os ativistas gays reivindicaram da presidente, o fim do veto dela ao Kit Escola sem Homofobia, gritando: "Ô Dilma, que papelão, não se governa com religião" (PORTAL DA DIVINA MISERICÓRDIA, s/d). Temos aqui a produção de um Estado articulado com interesses religiosos e contrários à concepção de uma família mais ampla.

Tais argumentos estão claramente articulados ao artigo 19 da Constituição Federal de 1988:

Art. 19. É vedado à União, aos Estados, ao Distrito Federal e aos Municípios: I - estabelecer cultos religiosos ou igrejas, subvencioná-los, embaraçar-Ihes o funcionamento ou manter com eles ou seus representantes relações de dependência ou aliança, ressalvada, na forma da lei, a colaboração de interesse público; II - recusar fé aos documentos públicos; III - criar distinções entre brasileiros ou preferências entre si (BRASIL, 1988).

Com tal normatização, traduz-se o Estado brasileiro como laico. Temos a produção da família homoafetiva passando por uma reivindicação da letra constitucional, em uma separação entre Estado laico e dogmas eclesiásticos.

Mais recentemente, em meio ao árido terreno da eleição presidencial brasileira de 2014, o candidato Levy Fidelix, em debate eleitoral com a candidata Luciana Genro, no dia 28 de setembro, na emissora Record, ao abordar família, afirma: "(...) dois iguais não fazem filho" (PORTAL R7, 2014). Mais ainda: "(...) aparelho excretor não reproduz" (PORTAL R7, 2014). Colocando o parâmetro da possibilidade de reprodução como pré-requisito para a existência de uma família, tais traduções acabam por gerar forte controvérsia em meio ao cenário eleitoral. Indo além, Fidelix ainda traduz os homossexuais como uma minoria que deveria ser enfrentada pela população (PASSARINHO, 2014).

Tais posicionamentos do candidato reverberaram de modo tão intenso que acabaram por levar a uma forte reação de internautas, conforme podemos observar no site Varela Notícias.

Os internautas reagiram quase imediatamente. As palavras "Levy" e "aparelho excretor" foram parar nos trending topics do Twitter brasileiro. Poucos minutos depois, a hashtag "LevyVocêÉNojento" ganhou força e virou um dos assuntos mais comentados na web. Um grupo chamado "Diga não à Homofobia" chegou até a criar uma campanha convocando o internauta a denunciar o político ao Ministério Público Federal (MPF) por homofobia (VARELA, 2014).

No portal G1 consta matéria de setembro de 2014 argumentando que tal colocação acabou por levar tanto a Organização dos Advogados do Brasil (OAB) como a candidata Luciana Genro a entrar com um pedido de punição junto ao Tribunal Superior Eleitoral (TSE) com o argumento de que Fidelix incitou o ódio contra homossexuais (PASSARINHO, 2014). É importante evidenciar que, apesar de infindáveis discussões sobre o modo como a união homoafetiva se encaixa naquilo que entendemos por família, a união estável, prevista na Constituição Federal, em seu art. 226, parágrafo terceiro e, no Código Civil, art. 1723, é tratada como entidade familiar e agregada no direito de família. E é essa nova interpretação que se estende aos casais homoafetivos pela decisão do STF. Nesse sentido, o Portal IG aponta que

(...) para ser considerada uma união estável, assim como para os casais heterossexuais, serão necessários alguns requisitos. Não há um prazo mínimo de convivência, mas a relação precisa ser uma convivência pública, duradoura, contínua, ter a característica de lealdade e com a intenção de se constituir família, segundo o próprio Código Civil. Com a decisão do STF, estende-se à união homoafetiva 112 direitos que até então eram exclusivos dos casais heterossexuais que vivem juntos (LEÃO; SIMAS; FARIELLO: 2011). 
Porém, os jornalistas ainda salientam que:

No entanto, algumas instituições ainda negam o reconhecimento da relação homossexual como entidade familiar. No ano passado, um clube de São Paulo recusou como sócio o companheiro de um gay (LEÃO; SIMAS; FARIELLO: 2011).

Podemos observar aqui, que a respectiva matéria acaba por demonstrar que, apesar da significativa mediação do STF, as redes que circulam aquilo que entendemos por família na atualidade ainda revelam instabilidade nas suas conexões com a relação homoafetiva.

\section{CONCLUSÃO}

Quando abordamos o tema família articulada à questão da união homoafetiva, podemos perceber uma intensa instabilidade desse artefato no cenário mundial. Na Inglaterra parece que, quando foi aprovada a união homoafetiva, houve maior aceitação do público do que, por exemplo, na França. Na Argentina, ainda que não possam realizar o matrimônio propriamente dito, a partir de 2001, os homossexuais passaram a gozar dos mesmos direitos que um casal heterossexual - como pensão em caso de morte e plano conjunto de assistência médica. À revelia da intensa controvérsia ainda existente, parece que a união homoafetiva circula na direção de uma maior estabilidade. No Brasil, por exemplo, no ano de 2011, como pudemos observar, o STF, no julgamento da ADPF 132 e ADI 4277, mostrou entendimento da união homoafetiva como sendo uma família.

Ainda em 2002, no Brasil, com o falecimento da cantora Cássia Eller, a concessão da guarda provisória de seu filho de oito anos à sua companheira revelou-se como um grande impacto naquele momento. Tal acontecimento parece ter sido bastante significativo no sentido de potencializar casos semelhantes, acabando por se articular a intensas lutas de argumentos e contra-argumentos, gerando fortes pressões, tanto a favor como contrárias ao delineamento legal dessa nova configuração de família.

Dentro do meio católico, enquanto o Papa emérito Bento XVI se colocava explicitamente contra os homossexuais e a união homoafetiva, o Papa Francisco parece demonstrar uma espécie de respeito à fé de um modo geral, mesmo que de uma pessoa homossexual. Sendo essas duas personalidades, os dois últimos líderes máximos da Igreja Católica, e sendo eles tratados, cada um em seu tempo, como retratos dessa religião, vê-se uma discordância de traduções de porta-vozes religiosos tão importantes.

No Congresso brasileiro encontramos uma forte oposição - pautada pela mídia - da dita bancada evangélica, com a forte presença do deputado e pastor Marco Feliciano, no sentido de que os homossexuais não ganhem direito ao casamento, traduzindo família dentro de um rígido modelo nuclear. Articulado a tal argumento, temos o pastor Silas Malafaia que faz a união homoafetiva circular por traduções como erro a ser confessado e pecado.

Disposto em lado contrário, o deputado federal Jean Willys, argumentando por uma isonomia no contexto do casamento e da família, se colocando como defensores do público LGBT e opositores de atitudes preconceituosas. Em meio a tais controvérsias, vê-se uma ampla discussão acerca da homossexualidade ser natural ou não, um embate entre determinismo genético ou social. Nesse terreno, encontramos, inclusive, traduções de homossexuais como sendo pecadores, devendo ser curados pela religião, em outros casos, encontram-se argumentos como sendo uma doença mental com fundo anatômico neurológico, os quais deveriam ser curados pela medicina - cura gay.

A controvérsia acerca do Projeto Escola sem Homofobia articula-se fortemente com tais embates. Diversas foram as pressões favoráveis ao veto do kit de combate a homofobia, distribuído Ministério da 
Saúde. Nesse sentido, a bancada evangélica e o deputado federal Jair Bolsonaro tiveram significativa ação. Este último se utilizando, inclusive, de termos hostis como "agenda antigay".

Enfim, ainda que haja uma série de controvérsias a respeito do tema, vemos na atualidade que a circulação de uma aceitação da diversidade sexual se mostra crescente, porém existe uma significativa dificuldade em sua propagação mais estabilizada. Se, no passado, a união estável foi uma vitória para os homossexuais, agora, o embate parece estar na questão da igualdade perante a lei e consequente aumento de sua potência social. À revelia das instabilidades que ainda vigoram, parece que cada vez mais o casamento homossexual se torna possível e plausível. Desse modo, a família parece ser um artefato a se imbricar com a causa LGBT da união homoafetiva com maior intensidade de modo gradativo, fazendo crer que a possibilidade de igualdade pode ser uma realidade. Família, assim, parece ser um artefato ainda instável, negociado pela ação de porta-vozes como pastores evangélicos, a grande mídia, a câmara, com seus deputados e senadores, políticos diversos, o STF e as legislações, a Igreja Católica, dentre outros.

\section{REFERÊNCIAS}

ALVES, R. R. Família patriarcal e nuclear: conceito, características e transformações. Anais do $2 .^{\circ}$ Seminário de Pesquisa da Pós-graduação em História UFG/UCC. 2009. Disponível em <http://www.cpgss.ucg. br/ArquivosUpload/16/file/Anais_II_Seminario_de_Pesquisa_da_Pos-Graduacao_em_Historia_UFGPUC_Goias/pdfs/IISPHist09_RoosembergAlves.pdf> Acesso em: 26 mai. 2014.

BORELLI, T. H. União homossexual: reflexões jurídicas. Jus Navigandi, Teresina, ano 8, n. 64, 1 abr. 2003. Disponível em <http://jus.com.br/artigos/3930> Acesso em: 26 mai. de 2014.

BOTTOLI, C.; BÜRGER, R. B.; CASTRO, L. M.; FERRÃO, N. R. Transformações da família nuclear para a família contemporânea: novas configurações. Anais do $5 .^{\circ}$ Interfaces do Fazer Psicológico: direitos humanos, diversidade e diferença. 2012. Disponível em <http://www.unifra.br/eventos/interfacespsicologia/ Trabalhos/3081.pdf> Acesso em 22 out. 2014.

BRASIL. Constituição da República Federativa do Brasil de 1988. 1988. Disponível em <http://www. planalto.gov.br/ccivil_03/constituicao/Constituicao.htm> Acesso em: 22 out. 2014.

BRASIL. Lei 10.406. 2002. Disponível em <http://www.planalto.gov.br/ccivil_03/leis/2002/l10406.htm> Acesso em: 22 out. 2014.

BRESCIANI, E. Em ato contra gays, Silas Malafaia diz que união homoafetiva é crime. O Estado de São Paulo on line. 2013. Disponível em <http://www.estadao.com.br/noticias/nacional,em-ato-contra-gayssilas-malafaia-diz-que-uniao-homoafetiva-e-crime,1039203,0.htm> Acessado em 12 de mai. de 2014.

CARTA CAPITAL. Comissão de Feliciano aprova plebiscito sobre casamento gay. Carta Capital. 2013. Disponível em <http://www.cartacapital.com.br/politica/comissao-de-feliciano-aprova-dois-projetoscontra-casamento-gay-9219.html> Acesso em: 22 out. 2014.

CHAGAS, A. Dois anos após veto, MEC diz que ainda 'analisa' kit anti-homofobia. Terra. 2013. Disponível em <http://noticias.terra.com.br/educacao/dois-anos-apos-veto-mec-diz-que-ainda-analisa-kitanti-homofobia,62a3a67b302be310VgnVCM10000098cceb0aRCRD.html> Acesso em: 22 out. 2014. 
CHAGAS, T. "Homossexual pode tornar-se heterossexual", diz pastor Silas Malafaia, que define prática como "comportamental"; Leia na íntegra. Gnotícias. 2013. Disponível em < http://noticias.gospelmais. com.br/homossexual-heterossexual-pastor-silas-malafaia-53350.html> Acesso em: 15 de set. de 2014.

COLARES, M. O que há de novo no Direito de Família? Jus Navigandi. 2001. Disponível em < http://jus. com.br/artigos/2044/o-que-ha-de-novo-no-direito-de-familia> Acesso em: 22 out. 2014.

DANTAS, A.C.D.; ARAÚJO, J. C. A. União estável homoafetiva ou união homoafetiva estável? Uma análise acerca do julgamento da ADI 4277 e ADPF 132 no STF. Anais do $1 .^{\circ}$ Congresso Brasileiro de Direito e Desenvolvimento: Sustentabilidade, Integração e Modernidade. 2012. Disponível em <http://www. direitoedesenvolvimento.net/anais/anais2012/gt01/06.pdf> Acesso em: 26 mai. de 2014.

FREIRE, G. Casa Grande \& Senzala: formação da família brasileira sob o regime da economia patriarcal. 21. ed. Rio de Janeiro: José Olympio, 1981.

GALDO, R. Mais votado no Rio para a Câmara, Bolsonaro mira a Presidência em 2018.

Jornal 0 Globo. 2014. Disponível em <http://oglobo.globo.com/brasil/mais-votado-no-rio-para-camarabolsonaro-mira-presidencia-em-2018-14171857\#ixzz3FYJnTK83> Acesso em: 22 out. 2014.

GONZÁLEZ, L. Maria Berenice Dias. Revista TPM. 2013. Disponível em <http://revistatpm.uol.com.br/ revista/129/paginas-vermelhas/maria-berenice-dias.html\#0> Acesso em 14 ago. 2014.

LEÃO,N.;SIMAS,F;;FARIELLO,D.VejaosdireitosqueoshomossexuaisganhamcomadecisãodoSTF.IG.2011.Disponívelem <http://ultimosegundo.ig.com.br/brasil/veja+os+direitos+que+os+homossexuais+ganham+com+a+decisao+do+stf/ n1300153607263.html> Acesso em: 22 out. 2014.

LATOUR, B. Ciência em ação: como seguir cientistas e engenheiros sociedade afora. São Paulo: Editora UNESP, 2000.

Reensamblar Lo Social: uma introdución a la teoria del actor-red. Buenos Aires: Manantial, 2008.

MEDINA, C. A. de. Família, Ontem, Hoje e Amanhã. IN: Debates Sociais. Editora CBCISS Reedição 1997. p.13- 27.

MOL, A. Política Ontológica. Algumas idéias e várias perguntas. In Nunes, J. A. \& Roque, R. (org.) Objectos impuros. Experiências em estudos sociais da ciência. Porto: Edições Afrontamento, 2007.

NOLETO, P. A. S.; LIMA, J. A. Homoafetividade e a união parcialmente civil. Psicologia. Pt. 2013. Disponível em <http://www.psicologia.pt/artigos/textos/TL0329.pdf> Acesso em: 26 mai. 2014.

OLIVEIRA, G. Exclusivo: deputado Marco Feliciano sobre casamento gay. Newsrondonia.com. 2013. Disponível em <http://www.newsrondonia.com.br/noticias/ exclusivo+deputado+marco+feliciano+sobre+casamento+gay/33759> Acesso em: 22 out. 2014.

OLIVEIRA, N. H. D. Recomeçar: família, filhos e desafios. Scielo Books. 2009. Disponível em <http:// books.scielo.org/id/965tk/pdf/oliveira-9788579830365-03.pdf> Acesso em: 26 mai. 2014.

PASSARINHO, N. OAB e Luciana Genro pedem ao TSE punição a Fidelix por fala sobre gays. G1. 2014. Disponível em <http://g1.globo.com/politica/eleicoes/2014/noticia/2014/09/oab-e-candidatos-vaoao-tse-contra-fala-de-fidelix-sobre-gays.html> Acesso em: 22 out. 2014. 
PINHEIRO, E. Marta ressalta Estatuto da Diversidade Sexual. PT no Senado. 2011. Disponível em <http://www.ptnosenado.org.br/textos/69-noticias/382-marta-criacao-de-estatuto-tem-relevanciainquestionavel> Acesso em 14 ago. 2014.

PORTAL DA DIVINA MISERICÓRDIA. Governo vai impor a homossexualidade nas escolas. Portal da Divina Misericórdia. s/d. Disponível em <http://www.misericordia.org.br/index.php?option=com_con tent\&view=article\&id=1636: governo-vai-impor-a-homossexualidade-nas-escolas\&catid=1:noticias\& Itemid=96> Acesso em: 22 out. 2014.

PORTAL R7. "Aparelho excretor não reproduz", diz Levy Fidelix em debate; assista. Portal R7. 2014. Disponível em <http://noticias.r7.com/eleicoes-2014/aparelho-excretor-nao-reproduz-diz-levy-fidelixem-debate-assista-29092014> Acesso em: 22 out. 2014.

REVISTA VEJA. Inglaterra realiza primeiros casamentos gays após nova lei. Revista Veja. 2014. Disponível em < http://veja.abril.com.br/noticia/mundo/reino-unido-legaliza-casamento-entre-homossexuais> Acesso em 22 out. 2014.

RITTO, C. Garotinho tenta opor gays a evangélicos no Rio. Revista Veja. 2012. Disponível em <http://veja. abril.com.br/noticia/brasil/garotinho-tenta-opor-gays-e-evangelicos-no-rio> Acesso em: 22 out. 2014.

SARDENBERG. C. M. B. E a família, como vai? Reflexões sobre mudanças nos padrões de família e no papel de mulher. Bahia: Análise \& Dados. 1997. Disponível em <http://www.ppgneim.ffch.ufba.br/_ARQ/ FAMILIASEI.pdf> Acesso em: 26 mai. 2014.

SBT. De Frente com Gabi. SBT. 2013. Disponível em < http://www.sbt.com.br/noticias/11630/Eu-amoos-homossexuais-como-eu-amo-os-bandidos-diz-Silas-Malafaia-no-De-frente-com-Gabi.html\#. VFvK8zTF-Yo> Acesso em 14 ago. 2014.

SITE FAMÍLIA BOLSONARO. O Kit Gay já chegou nas escolas privadas. Site Família Bolsonaro. 2012. Disponível em <http://familiabolsonaro.blogspot.com.br/2012/07/o-kit-gay-ja-chegou-nas-escolasprivadas.html> Acesso em: 22 out. 2014.

SUPLICY, M. Projeto de Lei n. ${ }^{\circ} 1151$ A. 1995. Disponível em <http://www.camara.gov.br/proposicoesWeb/ prop_mostrarintegra;jsessionid=7AB641A1544A197AE5D115E15793504B.node2?codteor $=982499 \&$ fil ename=Avulso+-PL+1151/1995> Acesso em 20 ago. 2014.

VARELA. Internautas se revoltam contra discurso de Levy Fidelix contra gays em debate. Varela Notícias. 2014. Disponível em <http://varelanoticias.com.br/internautas-se-revoltam-contra-discurso-de-levyfidelix-contra-gays-em-debate/> Acesso em: 22 out. 2014.

WILLYS, J. Álbum família pela igualdade. Natal, 2012. Casamento Igualitário. 2012. Disponível em < https://m.youtube.com/watch?v=-vrtd3tWy68> acesso em 22 out. 2014.

Casamento Igualitário. Casamento Civil Igualitário. s/d. Disponível em <http:// casamentociviligualitario.com.br/casamento-igualitario/> Acesso em 20 out. 2014.

ZANARDO, L.; VALENTE, M. L. L. C. Família e gênero na contemporaneidade. Revista de Psicologia da UNESP. 2009. Disponível em <http://www2.assis.unesp.br/revpsico/index.php/revista/article/ viewFile/129/152> Acesso em: 26 mai. 2014. 